\title{
Long-chain fatty alcohols from pomace olive oil modulate the release of pro-inflammatory mediators
}

\begin{abstract}
ANGELES FERNÁNDEZ-ARCHE ${ }^{*}$, ANA MARQUEZ-MARTíN ${ }^{a}$, ROCÍO DE LA PUERTA VAZQUEZ ${ }^{b}$, JAVIER S. PERONA ${ }^{a}$, CARMEN TERENCIO $^{c}$, CARMEN $^{2}$ PEREZ-CAMINO ${ }^{a}$ AND VALENTINA RUIZ-GUTIERREZ ${ }^{a}$
\end{abstract}

a Instituto de la Grasa (CSIC) Av. Padre García Tejero n 4. 41012. Seville. Spain.

${ }^{b}$ Department of Pharmacology, School of Pharmacy, University of Seville. C/ Profesor García González n². 41012. Seville. Spain.

c Department of Pharmacology, School of Pharmacy, University of Valencia. Av.Vicente Andrés s/n. 46100. Burjassot, Valencia. Spain.

${ }^{*}$ Corresponding author: Javier S. Perona

Instituto de la Grasa. Av. Padre Garcia Tejero, 4. 41012 Seville (Spain.

Tel: +34954611550

Fax.: +34954616790

E-mail: perona@ig.csic.es

Running title: Long-chain fatty alcohols and inflammatory mediators

Acknowledgements: This study has been supported by funds from "Comision Interministerial de Ciencia y Tecnologia "(CICYT AGL2002-00195 and AGL200500572).

Key words: Pomace olive oil, long-chain fatty alcohols, macrophages, nitric oxide; inflammation, cytokine. 


\section{SUMMARY}

Pomace olive oil is a byproduct of olive oil extraction that is traditionally produced and consumed in Spain. The non-glyceride matter of this oil is a good source of interesting minor compounds, like long-chain fatty alcohols, which are present free or as part of waxes. In the present study, long-chain fatty alcohols were isolated from the nonglyceride fraction of pomace olive oil and the composition was identified and quantified. The major components of long-chain fatty alcohols were tetracosanol, hexacosanol and octacosanol. We investigated the ability of long-chain fatty alcohols from pomace olive oil to inhibit the release of different pro-inflammatory mediators in vitro by cells involved in inflammatory processes. Long-chain fatty alcohols significantly and dosedependently decreased nitric oxide production by RAW 264.7 murine macrophages stimulated with lipopolysaccharide. Western-blot analysis showed that nitric oxide reduction was a consequence of the inhibition of iNOS expression. Long-chain fatty alcohols also reduced TNF- $\alpha$ and prostaglandin E2 production, although the potency of inhibition for the latter was lower. On the other hand, long-chain fatty alcohols significantly reduced thromboxane $A_{2}$ production in rat peritoneal neutrophils stimulated with the calcium ionophore A-23187. The reduction of eicosanoid release was related to the inhibition of phospholipase $A_{2}$ enzyme activity by long-chain fatty alcohols, reaching an $\mathrm{IC}_{50}$ value of $6.2 \mathrm{\mu g} / \mathrm{ml}$. These results showed that long-chain fatty alcohols may have a protective effect on some mediators involved in the inflammatory damage development, suggesting its potential value as a putative functional component of pomace olive oil. 


\section{INTRODUCTION}

Virgin olive oil (VOO), a source of healthy micronutrients, may be regarded as a functional food due to its important beneficial effects. An increasing number of studies are pointing out the important biological effects of some of these micronutrients and that the content of oleic acid can not fully explain the impact of VOO on health $[1,2]$ Minor components of $\mathrm{VOO}$, found in the non-glyceridic fraction, may also explain some of the healthy effects of the Mediterranean diet [3,4]. Pomace olive oil (POO) is obtained from the wastes after the extraction of VOO by mechanical procedures and contains components from the leaves, skin and seeds. Despite the glyceridic fraction being similar [5], some of the minor components are present in higher concentration in POO than in VOO $[6,7]$. Thus, the unsaponifiable fraction of POO contains elevated amounts of sterols, tocopherols, waxes and triterpenic acids and alcohols with important biological activities. Among these, recent investigations have revealed the vasorelaxant, antioxidant and anti-inflammatory properties of erythrodiol and oleanolic and maslinic acids [2,8-10].

Another fraction of the minor components of $\mathrm{POO}$ that has received insufficient attention to date is that of long-chain fatty alcohols (LCFA). These compounds are usually found in waxes of common foods and have been isolated from sugarcane, spinach and beeswax by saponification and solvent extraction. A number of beneficial physiological activities have been attributed to LCFA, such as reducing platelet aggregation, endothelial damage and cholesterol lowering effects $[11,12]$. All these studies have been carried out using "Policosanol", a commercialized mixture of LCFA $[13,14]$, whose major components are octacosanol (C28), triacontanol (C30) and hexacosanol (C26). Octacosanol, is in fact known for its antiaggregant effect, as an alternative to aspirin for patients suffering from gastric irritation due to its cytoprotective effects [15]. Although present in relatively high concentrations, the biological activities of LCFA from POO have not been studied yet.

Nitric oxide (NO) has been shown to play a central role in inflammatory and immune reaction activities. Macrophages appear to be the main cellular source of NO since these cells significantly contribute to inducible NO synthetase (iNOS) induction after lipopolysacharide (LPS) incubation [16]. NO is also able to enhance the production of tumour necrosis factor- $\alpha$ (TNF- $\alpha$ ) and IL-1 $\beta$ cytokines, which participate in the macrophage-dependent inflammation [17]. Activation of macrophages also leads to ciclooxygenase 2 (COX-2) stimulation with consequent prostaglandin $E_{2}\left(P E_{2}\right)$ 
overproduction, which plays a key role in the pathogenesis of inflammatory processes [18]. Another eicosanoid of particular importance is thromboxane $A_{2}\left(T X A_{2}\right)$, which is produced by the action of thromboxane synthase on the prostaglandin endoperoxide $\mathrm{H}$ $2\left(\mathrm{PGH}_{2}\right)$ resulting from the enzymatic transformation of arachidonic acid by the COX2. $\mathrm{TXA}_{2}$ is a potent inducer of platelet aggregation, vasoconstriction and broncchoconstriction, and has been involved in a series of major pathophysiological conditions [19].

Arachidonic acid is released from phospholipids by the action of the secretory phospholipase $A_{2}\left(s P L A_{2}\right.$ ), thereby providing the substrate for the biosynthesis of proinflammatory eicosanoids. $\mathrm{SPLA}_{2}$ is released in plasma and other biologic fluids of patients with systemic inflammatory, autoimmune, and allergic diseases. Different isoforms of $\mathrm{sPLA}_{2}$ are expressed and released by several cells types, such as neutrophils, basophils, T-cells, monocytes, macrophages, and mast cells where promotes cytokine and chemokine production. Thus, $\mathrm{sPLA}_{2}$ might play important roles in the initiation and amplification of inflammatory reaction [20,21]. Therefore, the inhibition of $\mathrm{PLA}_{2}$ could result in down-regulation of the inflammatory response, acting at an early step of several inflammatory mediator biosynthesis.

The aim of our study was to analyze and identify the composition of the LCFA fraction, isolated from $\mathrm{POO}$ and to examine its ability to inhibit the release of some proinflammatory mediators by cells involved in inflammation. With this purpose, we investigated the effect of LCFA to inhibit the SPLA $\mathrm{A}_{2}$ enzyme activity, in vitro and on NO, $\mathrm{PGE}_{2}$ and TNF $\alpha$ generation in LPS-stimulated RAW-macrophages, as well as the $\mathrm{TXA}_{2}$ produced in rat peritoneal polymorphonuclear neutrophils, stimulated with the calcium ionophore A-23187. 


\section{METHODS AND MATERIALS}

\section{Sample preparation}

The unsaponifiable fraction of POO was isolated following conventional procedures. In brief, POO was saponified with $25 \mathrm{ml}$ of $2 \mathrm{mM} \mathrm{KOH}$ in methanol:water (80:20, v/v). After heating at $70^{\circ} \mathrm{C}$ for $30 \mathrm{~min}, 50 \mathrm{ml}$ of water and $50 \mathrm{ml}$ of ethyl ether were added. The unsaponifiable fraction was collected by decantation and its components were analyzed following the IUPAC method [22]. $1.5 \mathrm{~g}$ of the unsaponifiable fraction was fractioned on a silica gel column and the LCFA subfraction eluted with a mixture of hexane and ethyl ether $(85: 15, v / v)$. The same procedure was used to obtain the LCFA fraction that was added to the cell culture medium at appropriate concentrations. For LCFA analysis by gas chromatography, the isolated LCFA were transformed into trimethylsilyl ethers by adding $200 \mu \mathrm{L}$ of a mixture of $9: 3: 1 \mathrm{v} / \mathrm{v} / \mathrm{v}$ of pyridinehexamethyldisilazane-trimethylchlorosilane.

\section{Gas-Chromatography conditions}

LCFA were analyzed with a Chrompack (Middelburg, The Netherlands) CP900 gas chromatograph equipped with a capillary column SGL-5, of $30 \mathrm{~m}$ lenght, $0.25 \mathrm{~mm}$ i.d and $0.25 \mu \mathrm{m}$ film thickness of $5 \%$ phenyl methylpolysiloxane stationary phase. Carrier gas was hydrogen, with a head pressure of $110 \mathrm{KPa}$ and 1:60 split ratio. Injector temperature was $280^{\circ} \mathrm{C}$ and detector temperature $290^{\circ} \mathrm{C}$. The oven temperature was programmed from $215^{\circ} \mathrm{C}$ to $290{ }^{\circ} \mathrm{C}$ with a rate of $2^{\circ} \mathrm{C} /$ minute. The analysis was carried

out following the method of the Commission Regulation (EC) N $N^{\circ} 1989 / 2003$. Amending Regulation (EC) 2568/91 on the characteristics of olive and the relevant method of analysis. Total LCFA concentration in POO was calculated as the sum of individual LCFA concentrations.

\section{Reagents}

[5,6,8,11,12,14,15 (n)- $\left.{ }^{3} \mathrm{H}\right] \mathrm{PGE}_{2}$ was from Amersham Biosciences (Madrid, Spain). [9, $10-{ }^{3} \mathrm{H}$ ] Oleic acid was purchased from Du Pont, (Itisa, Madrid, Spain). Mouse TNF- $\alpha$ and $\mathrm{TXB}_{2}$ ELISA were from BLK Diagnostics (Badalona, Spain). The rest reagents were purchased from Sigma Aldrich Chem. (St. Louis, MO, U.S.A.). Stock solutions of compounds were prepared in DMSO and later dissolved in ethanol. The final concentration of DMSO or ethanol in the culture medium did not significantly influence 
cell response. The quantities of the compounds are expressed as their final concentration in the culture medium.

\section{Assay of sPLA}

Secretory phospholipase $A_{2}$ was assayed by using a modification of the method of Franson [23]. Escherichia coli strain CECT 101 were seeded in medium containing 1\% tryptone, $0.5 \% \mathrm{NaCl}$ and $0.6 \%$ sodium dihydrogen ortophosphate, $\mathrm{pH} 5.0$ and grown for 6 to $8 \mathrm{~h}$ at $37^{\circ} \mathrm{C}$ in the presence of $5 \mu \mathrm{Ci} \mathrm{Ci} / \mathrm{ml}^{3} \mathrm{H} /$ oleic acid (sp. Act. $10 \mathrm{Ci} / \mathrm{mmol}$ ). After centrifugation at $2500 \mathrm{~g}$ for $10 \mathrm{~min}$, the cells were washed in buffer $(0.7 \mathrm{M}$ tris$\mathrm{HCl}, 10 \mathrm{mM} \mathrm{Ca} \mathrm{Cl}, 0.1 \% \mathrm{BSA}, \mathrm{pH}$ 8.0) resuspended in saline and autoclaved for 30 to $45 \mathrm{~min}$. At least $95 \%$ of the radioactivity was incorporated into phospholipids. Human recombinant synovial enzyme was added to a solution of $100 \mathrm{mM}$ (Tris $\mathrm{HCl}, 1 \mathrm{mM} \mathrm{Ca}$ $\mathrm{Cl}_{2}$ buffer $\mathrm{pH} 7.5$ ), and preincubated at $37^{\circ} \mathrm{C}$ for 5 min with $2.5 \mu \mathrm{l}$ of test compound solution at different doses $(1,5,10,50$ and $100 \mu \mathrm{g} / \mathrm{ml})$ or its vehicle in a final volume of $250 \mu \mathrm{l}$. Incubation proceeded for $15 \mathrm{~min}$ in the presence of $10 \mu \mathrm{l}$ of autoclaved oleatemembranes and was terminated by addition of $100 \mu \mathrm{l}$ ice-cold solution of $0.25 \%$ BSA in saline to a final concentration of $0.07 \% \mathrm{w} / \mathrm{v}$. After centrifugation at $2500 \mathrm{~g}$ for $10 \mathrm{~min}$ at $4^{\circ} \mathrm{C}$, the radioactivity in the supernatants was determined by liquid scintillation counting. The inhibitory effect was measured in relation to control enzyme activity (radioactivity in cpm.) in tubes containing enzyme.

\section{Cell viability}

The mitochondrial dependent reduction of 3-(4,5-dimethylthiazol-2-yl)-2,5diphenyltetrazolium bromide (MTT) to formazan was used to asses the possible cytotoxic effect on the mouse macrophage cell line RAW 264.7.

\section{Culture of murine macrophage RAW 264.7 cell line}

The mouse macrophage cell line RAW 264.7 (Cell Collection, Department of Animal Cell Culture, C.S.I.C., Madrid, Spain) was maintained in Dubelcco's Modified Eagle's Medium (DMEM) supplemented with L-glutamine $2 \mathrm{mM}, 100 \mathrm{U} / \mathrm{ml}$ penicillin, $100 \mu \mathrm{g} / \mathrm{ml}$ streptomycin and $10 \%$ heat inactivated foetal bovine serum (FBS). Macrophages were removed from the tissue culture flask using a cell scraper and centrifuged at $800 \mathrm{~g}$ for $10 \mathrm{~min}$. Cells were resuspended at a concentration of $1 \times 10^{6} \mathrm{cell} / \mathrm{ml}$ in a total volume of $200 \mu \mathrm{l}$ and culture in 96 well culture plate. 


\section{Nitrite, $\mathrm{PGE}_{2}$ and TNF- $\alpha$ production in Raw 264.7 macrophages}

RAW 264.7 macrophages $\left(1 \times 10^{6}\right.$ cell $\left./ \mathrm{ml}\right)$ were co-incubated with $10 \mu \mathrm{g} / \mathrm{ml}$ of Escherichia coli (serotype $0111: \mathrm{B}_{4}$ ) LPS at $37^{\circ} \mathrm{C}$ for $24 \mathrm{~h}$ in the presence of LCFA fractions at different doses $(25,50$ or $100 \mu \mathrm{g} / \mathrm{ml}$ ) or vehicle. Nitrite (as index of NO generation) was determined in culture supernatants by a flurometric method [24]. $\mathrm{PGE}_{2}$ and TNF- $\alpha$ levels production were quantified by sandwich immunoassay $[25,26]$.

\section{Western blot analysis of iNOS expression}

To induce iNOS expression, RAW 264.7 cells $\left(2 \times 10^{6}\right.$ cell $\left./ \mathrm{ml}\right)$ were incubated with LPS $(10 \mu \mathrm{g} / \mathrm{ml})$ in 6 -well culture plate in the presence of the highest fraction concentrations $(100 \mu \mathrm{g} / \mathrm{ml})$. Dexamethasone at $10 \mu \mathrm{M}$ was used as standard reference of iNOS gene expression inhibition. After $18 \mathrm{~h}$ stimulation, medium was removed and cells were washed twice with PBS $25 \mathrm{mM}$, then cells were lysed with lysis buffer ( $1 \%$ triton X-100, $1 \%$ deoxycholic acid, $20 \mathrm{mM} \mathrm{NaCl}$, and $25 \mathrm{mM}$ Tris, $\mathrm{pH} 7.4$ ). Following centrifugation (10000 g, $15 \mathrm{~min}$ ), protein was determined in supernatants, by the DC Bio-Rad protein assay reagent (Bio-Rad, Hercules, Ca., USA). Equal amounts of protein $(25 \mu \mathrm{g})$ were loaded on 12\% SDS-PAGE and transferred onto pure nitrocellulose membranes for 90 min at $125 \mathrm{~mA}$. Membranes were blocked in PBS-Tween 20 containing 3w/w unfatted milk. Membranes were incubated with specific iNOS polyclonal antibody (1/1500 dilution; Santa Cruz, California); blots were washed and incubated with peroxidaseconjugated goat anti-rabbit Ig G (1/3500 dilution; DAKO, Denmark). The inmunoreactive bands were visualized using enhanced chemiluminiscence system (ECL; Amersham Biosciences, Madrid, Spain).

\section{$\mathrm{TXB}_{2}$ release by $\mathrm{A}-23187$ stimulated rat neutrophils}

Leukocytes containing approximately $85 \%$ polymorphonuclear leukocytes (PMNs) and $15 \%$ mononuclear cells were prepared [25] from male Wistar rats and resuspended in complete HBSS at $0.5 \times 10^{6}$ cells $/ \mathrm{mL}$ containing $1.26 \mathrm{mM} \mathrm{Ca}^{2+}$ and $0.9 \mathrm{mM} \mathrm{Mg}^{2+}$. Cell viability based on trypan blue exclusion was greater than $95 \%$. Triplicate aliquots of 0.5 $\mathrm{mL}$ leukocytes were preincubated at $37^{\circ} \mathrm{C}$ for $10 \mathrm{~min}$ with $2 \mu \mathrm{L}$ dimethylsulphoxide (DMSO) containing LCFA. After this, $5 \mu \mathrm{L}$ of calcium ionophore A23187 was added in DMSO to give a final concentration of $1 \mu \mathrm{M}$ for a further $10 \mathrm{~min}$ of incubation. The cells were pelleted by centrifugation at $2500 \mathrm{~g}$ for $10 \mathrm{~min}$ at $4^{\circ} \mathrm{C}$, and the supernatants were 
decanted and frozen. For the $\mathrm{TXB}_{2}$ assay aliquots the supernatant were subjected to a commercially available sandwich immunoassay kit.

\section{Data analysis}

The results are presented as mean \pm SEM; inhibitory concentration $50 \%\left(\mathrm{IC}_{50}\right)$ values were calculated from at least three concentrations. Statistically significant differences were evaluated by analysis of variance (ANOVA) followed by Dunnet's t-test for multiple comparisons. 


\section{RESULTS}

\section{Analysis of the sample composition}

LCFA were isolated from the POO unsaponificable fraction and its constituents were identified by gas chromatography (Figure 1) as a mixture of very-long-chain aliphatic alcohols, whose main components were: docosanol (C22) (7.5\%), tetracosanol (C24) (30.3\%), hexacosanol (37.3\%) and octacosanol (15.3\%) (Table 1). Additionally, small concentrations of the odd series, $n=23,25,27$ and terpenic alcohols as phytol $(\mathrm{C} 2 \mathrm{OH} 40 \mathrm{O})$ or geranylgeraniol $(\mathrm{C} 2 \mathrm{OH} 34 \mathrm{O})$ were also detected. Total LCFA concentration in POO was $1853 \mathrm{mg} / \mathrm{kg}$, calculated as the sum of individual LCFA concentrations.

\section{Inhibition of sPLA 2 activity}

As shown in Figure 2, the LCFA fraction was revealed as an effective inhibitor of human recombinant synovial phospholipase $A_{2}$ activity at all assayed doses (1-100 $\mu \mathrm{g} / \mathrm{mL}$ ), reaching an $\mathrm{IC}_{50}$ value of $6,2 \mu \mathrm{g} / \mathrm{ml}$. The percentage of inhibition ranged from about $6.5 \%$ at $1 \mu \mathrm{g} / \mathrm{mL}$ to $68 \%$ at $100 \mu \mathrm{g} / \mathrm{mL}$.

\section{Effect of LCFA on cell viability}

LCFA did not induced toxicity in the macrophage cell line when assessed by mitochondrial reduction of MTT after $24 \mathrm{~h}$ treatment. Viability of cells treated with LCFA was $87 \pm 0.8 \%, 95 \pm 0.8 \%$ and $99 \pm 0.5 \%$ at LCFA concentrations $100 \mu \mathrm{g} / \mathrm{ml}, 50 \mu \mathrm{g} / \mathrm{ml}$ and $25 \mu \mathrm{g} / \mathrm{ml}$, respectively.

\section{Nitrite, $\mathrm{PGE}_{2}$ and TNF $\alpha$ production by LPS-stimulated RAW 264.7 macrophages}

The effect of LCFA on the release of inflammatory mediators by LPS-stimulated RAW 264.7 macrophages is depicted in Figure 3. Co-incubation with LCFA significantly reduced nitrite production, in a dose dependent manner, with an $\mathrm{IC}_{50}$ value of 53.4 $\mu \mathrm{g} / \mathrm{ml}$ (Figure 3A). The highest inhibition was achieved at $100 \mu \mathrm{g} / \mathrm{mL}(88 \%)$ but even at the lowest concentration assayed $(1 \mu \mathrm{g} / \mathrm{mL})$, an inhibition of $20 \%$ was observed. 
Likewise, $\mathrm{PGE}_{2}$ generation was also reduced by LCFA at all doses assayed although the percentage of inhibition was lower than that of nitrite (Figure $3 \mathrm{~B}$ ). The highest inhibition was found at $100 \mu \mathrm{g} / \mathrm{mL}$ and was quantified as $38 \%$ of total $\mathrm{PGE}_{2}$ production. In contrast, LCFA were able to significantly inhibit TNF- $\alpha$ generation only at the highest dose assayed $(100 \mu \mathrm{g} / \mathrm{ml}$ ) (Figure $3 \mathrm{C}$ ). Nevertheless, the percentage of inhibition was very high (83\%).

\section{iNOS expression}

Western blot assay in LPS-stimulated RAW 264.7 macrophages was performed to assess possible effects on iNOS enzyme gene expression. Figure 4 shows that LCFA at $100 \mu \mathrm{g} / \mathrm{ml}$ caused a complete inhibition of the LPS-induced iNOS expression $(100 \%)$. This effect was similar to dexamethasone, the reference compound.

\section{Effect of LCFA on the $\mathrm{TXB}_{2}$ release by rat neutrophils}

LCFA inhibited $\mathrm{TXA}_{2}$ generation (measured as $\mathrm{TXB}_{2}$ ) release by rat neutrophils stimulated with calcium ionophore A.23187 at all assayed doses (Figure 5). The concentration-dependent study showed an IC50 value of $56.17 \mu \mathrm{g} / \mathrm{ml}$. 


\section{DISCUSSION}

POO is a byproduct of VOO extraction, obtained from the wastes originated after the first pressing of the olive fruit. The new improved procedure for POO extraction by centrifugation, instead of using organic solvents, allows the presence of higher concentrations of interesting minor components from the olive fruit and leaves. The present study demonstrates that a fraction isolated from $\mathrm{POO}$, constituted by LCFA, is able to reduce the generation of mediators involved in the inflammatory response in different experimental models.

Chemical and nutritional studies have shown that mixtures of long-chain primary alcohols extracted from waxy materials from different sources, such as beeswax, rice bran, wheat germ, sugar cane and grain sorghum, are able to exert several beneficial physiological effects. The main linear aliphatic alcohols present in olive oil are tetracosanol (C24), hexacosanol (C26), octacosanol (C28) and docosanol (C22) and are found in significantly larger amounts in POO than in VOO [27]. In agreement with these authors, the main fatty alcohol present in the LCFA fraction isolated from POO was hexacosanol (37.3\%), followed by tetracosanol (30.3\%), octacoasnol (15.3\%) and docosanol $(7.5 \%)$, accounting for $90 \%$ of total LCFA. This composition is slightly different of that of policosanol, a commercial mixture of verylong-chain alcohols composed mainly of octacosanol ( 60\%), triacontanol $(\sim 13 \%)$ and hexacosanol ( 6\%) [12]. A number of clinical studies have documented the ability of policosanol to reduce serum cholesterol, $[11,14,28]$ although a very recent clinical study was unable to find a significant cholesterol-lowering effect [29]. Other studies had demonstrated that this alcohol mixture, administrated orally to rabbits was effective in preventing the development of atherosclerosis lesions in the aorta [11]. Atherosclerosis is considered a low-grade chronic inflammatory disease as it shows many of the hallmarks of an inflammatory disease [30]. Many studies have shown that the process of atherogenesis in part starts with the interaction between activated leucocytes and activated endothelium [31]. Molecules including cytokines, chemokines, growth factors and prostanoids have an important role in vascular homeostasis.

Macrophages play a key role in the development of the atherosclerotic lesion [32]. The onset of atherosclerosis involves attraction of monocytes to the vessel wall at local sites of endothelial dysfunction. The monocytes subsequently migrate through the endothelium and differentiate into macrophages. Atherogenesis is accompanied by the local production and secretion of inflammatory mediators, for which the macrophage is 
a major source. Activated macrophages secrete eicosanoids, nitric oxide, and proinflammatory cytokines, which play a key role in the pathogenesis of the inflammatory disease. Thus, the expression and activity of iNOS and COX-2 greatly modulate the synthesis of $\mathrm{NO}$ and prostaglandins and hence, the inflammatory response. Shinbori et al., [33] have recently reported that haxacosanol (C26) can improve diabetes-induced hypercontraction by down-regulation of iNOS expression. Our study demonstrates that LCFA are able to inhibit nitrite production from LPSstimulated RAW 264.7 macrophage culture without indication of cytotoxicity. The reduction of nitrite concentrations in supernatants of cells co-incubated with LPS and the fraction tested can be either due to an interference with the enzyme induction by LPS or due to a direct action of LCFA on iNOS activity. Western blot analysis showed that the LCFA fraction is highly involved in iNOS protein expression. Thus, this fraction may selectively inhibit the enhanced iNOS expression and might control high production of NO during inflammatory or immune conditions. Statins are potent hypoholesterolemic drugs, which have been shown to suppress iNOS gene expression in RAW264.7 macrophages [34]. Like statins, LCFA are also hydroxymethyl-glutarylcoenzyme A (HMG-CoA) reductase inhibitors and, in fact, the cholesterol-lowering effect of policosanol has been attributed to this activity [12]. For this reason, it has been hypothesized that LCFA might mimic the effect of statins on iNOS expression [35]. Should this hypothesis turns out to be correct, LCFA might modulate nitric oxide release by acting on iNOS transcription, probably by inactivating the nuclear transcription factor NFkB, just as statins do [36].

LCFA also reduced TNF $\alpha$ production by LPS-stimulated RAW 264.7 macrophages, but only at the highest concentration tested $(100 \mu \mathrm{g} / \mathrm{mL})$. Hexacosanol has also been shown to decrease cytokine concentrations in the kidney of streptozotocin-induced diabetic rats [37]. In fact, Muller et al., [38] reported that synthetic LCFA, bearing an $\alpha$-tocopherol moiety, reduce TNF $\alpha$ secretion by LPSactivated microglia. According to these authors, this effect would be also mediated by $\mathrm{NF} \kappa \mathrm{B}$ activation. This transcription factor is also involved in COX-2 transcription [39], the enzyme responsible for the synthesis of PGE2. Our results show that LCFA also reduce PGE2 release in a dose-dependent manner, although the effect was not so potent. Therefore, our results overall suggest that the effect of the LCFA fraction from POO might be mediated by the inactivation of NFKB. 
As well as promoting cytokine and chomokine production by macrophages, $\mathrm{SPLA}_{2}$ releases arachidonic acid from phospholipids, providing the substrate for the biosynthesis of PGE2 by COX-2. Therefore, $\mathrm{SPLA}_{2}$ plays an important pathophysiological role in the initiation and amplification of the inflammatory reaction [20]. LCFA isolated from POO revealed as potent inhibitors $\left(\mathrm{IC}_{50}: 6.2 \mu \mathrm{g} / \mathrm{ml}\right)$ of human recombinant $\mathrm{SPLA}_{2}$ in vitro. IC50, or the half maximal inhibitory concentration, represents the concentration of particular molecule that is required to inhibit some biological processes by $50 \%$ and is used as a measure of this molecule potency; therefore the smaller IC50 the less molecule amount needed to exert a biological process. In our study only $6.2 \mu \mathrm{g} / \mathrm{ml}$ of LCFA was needed to inhibit PLA2 production by $50 \%$, which shows the high potency of LCFA. The reduction of de PLA $\mathrm{P}_{2}$ enzymatic activity was even significant at the lowest dose assayed $(1 \mu \mathrm{g} / \mathrm{mL})$. These promising results, in the experimental model used, suggest that LCFA fraction could have a possible role as functional component of POO.

Neutrophils migrate to the site of inflammation and, upon activation by different stimuli, generate large amounts of pro-inflammatory mediators including $\operatorname{TXA}_{2}$, an arachidonic-derived bioactive metabolite with particular importance in the pathogenesis of inflammatory and thromboembolic diseases. $\mathrm{TXA}_{2}$ is produced by the action of thromboxane synthase on the prostaglandin endoperoxide $\mathrm{H}_{2}\left(\mathrm{PGH}_{2}\right)$, which results from the enzymatic transformation of arachidonic acid by COX. It is a potent inducer of platelet aggregation, vasoconstriction and bronchoconstriction, and has been involved in a series of major pathophysiological conditions [40]. LCFA significantly reduced $\mathrm{TXA}_{2}$ (measured as $\mathrm{TXB}_{2}$ ) in a dose-dependent manner after overproduction by calcium ionophore A23187-stimulated neutrophils. These results agree with other others experimental studies carried out with policosanol. This mixture of LCFA has been reported to lower $\mathrm{TXA}_{2}$ serum levels in both animals and humans, which was accompanied to arachidonic acid-induced platelet aggregation $[14,41]$

A number of very recent investigations are pointing out that $\mathrm{POO}$ or some its components may have potent activities against the development of atherosclerosis $[2,8,9,42]$. Our study demonstrated that the LCFA fraction, isolated from POO, can reduce the release of different inflammatory mediators (eicosanoids, cytokines and NO) by interfering in different stages of their metabolic pathways, like iNOS expression or $\mathrm{PLA}_{2}$ activity. Thus, the present results suggest that the LCFA fraction may confer a protective role to $\mathrm{POO}$ against inflammatory damage in different pathologies, including atherosclerosis. 


\section{REFERENCES}

1.Owen RW, Mier W, Giacosa A, Hulel WE, Spiegelhalder B, Bartsch H. Phenolic compounds and squalene in olive oils: the concentration and antioxidant potential of total phenols, simple phenols secoroids, lignans ans squalene. Food Chem Toxicol. 2000;38:647-59.

2. Perona J, Arcemis C, Ruiz-Gutierrez V, Catalá A. Effect of dietary high-oleic-acid oils that are rich in antioxidants on microsomal lipid peroxidation in rats. J Agric Food Chem 2005;53:730-5.

3. Moreno JJ. Effect of olive oil minor components on oxidative stress and arachidonic acid mobilization and metabolism by macrophages Raw 264.7. Free Rad Biol Med. 2003;35:1073-81.

4. De la Puerta R, Martinez-Dominguez E, Ruiz-Gutierrez V. Effects of minor compound of virgin olive oil on topical anti-inflammatory assays. Z, Naturfoschung. 2000;55:814-9.

5.Guillen MD, Sopelana P, Palencia G. Polycyclic aromatic hydrocarbons and olive pomace oil. J. Agric Food Chem. 2004;52:2123-32.

6. Vioque E, Morris LJ. Minor components of olive oils I. Triterpenoid acids in an acetone-extracted orujo oil. J Am Oil Chem Soc. 1961;38:485-8.

7. Perez-Camino MC, Cert A. Quantitative determination of hydroxy pentacyclic triterpene acids in vegetable oils. J Agric Food Chem. 1999;47:1558-62.

8. Rodriguez-Rodriguez R, Herrera MD, Perona JS, Ruiz-Gutierrez V. Potential vasorelaxant effects of oleanolic acid and erytrodiol, two triterpenoids contained in 'orujo' olive oil, on rat aorta. Br J Nutr. 2004;92:635-42.

9. Rodriguez-Rodriguez R, Herrera MD, Ruiz-Gutierrez V Functional properties of pentacyclic triterpenes contained in "orujo" olive oil. Curr Nutr Food Sci. 2006;2:45-9.

10. Marquez-Martin A, de la Puerta R, Fernandez-Arche A, Ruiz-Gutierrez V, Yaqoob $P$. Modulation of cytokine secretion by pentacyclic triterpenes from olive pomace oil in human mononuclear cells. Cytokine. 2006;36:211-7.

11. Arruzazabala ML, Carbajal D, Mas R, Molina V, Valdes S, Laguna A. Cholesterollowering effects of policosanol on normocholesterolemic rabbits. Biol Res. 1994;27:205-10.

12. Singh DK, Li L, Porter TD. Policosanol inhibits cholesterol synthesis in hepatoma cells by activation of AMP-kinase. J Pharmacol Exp Ther. 2006;318:1020-6.

13. Irmak, S, Dunford NT, Milligan J. Policosanol contents of beeswax, sugar cane and wheat extracts. Food Chem. 2005;95:312-8. 
14. Arruzazabala ML, Noa M, Menéndez R, Mas R, Carvajal D, Valdes S, Molina V. Protective effect of policosanol on atherosclerotic lesions in rabbits with exogenous hipercolesterolemia. Braz J Med Biol Res. 2000;33:835-40.

15. Taylor JC, Rapport L, Lockwood GB. Octacoasonol in human health. Nutriton. 2003;19:192-5.

16. Salkowski CA, Detore G, Mcnally R, van Rooijen N, Vogel SN. Regulation of inducible nitric oxide synthase messenger RNA expression and nitric oxide production by lipopolysaccharide in vivo: the roles of macrophages, endogenous IFN-gamma, and TNF receptor-1-mediated signalling. J Inmunol. 1997;158:905-12.

17.Marcinkiewiez J, Grabowska A, Chain B. Nitric oxide upregulates the release of inflammatory mediators by mouse macrophages. Eur J Inmunol. 1995;25:947-51.

18. Kang RI, Freire-Moar J, Sigal E, Chu CQ Expression of cyclooxygenase-2 in human and animal model of rheumatoid arthritis. $\mathrm{Br} \mathrm{J}$ Rheumatol. 1996;35:711-8.

19. Dogné JM, Hanson J., de Leval X, Pratico D, Pace-Asciak CR, Drion P, Pirotte B, Ruan $\mathrm{KH}$. From the design to the clinical application of thromboxane modulators. Curr Pharm Des. 2006;12;903-23.

20. Triggiani M, Granata F, Giannattasio G and Marone G. Secretry phospholipase a2 in inflammatory and allergic diseases:Not just enzymes. J Allergy Clin Inmunol. 2005;116:1000-6.

21. Masuda S, Murakami M, Ishikawa Y, Ishii T, Kudo I. Diverse cellular localizations of secretory phospholipase A2 enzymes in several human tissues. Biochim Biophys Acta. 2005;1736:200-10.

22. Paquot C. Determinacion of the unsaponifiable matter. Method 2401. In: Paquot $C$, Hautfenne, A. editors. IUPAC Standard Methods for the analysis of oils, fats and derivatives, $7^{\text {th }}$ ed., revised and enlarged. Oxford: Blackwell; 1992.

23. Franson R, Patriarca $P$, Elsbach $P$ Phospholipid metabolism by phagocytic cells. Phospholipases A2 associated with rabbit polymorphonuclear leukocyte granules. J Lipid Res. 1974;15:380-8.

24. Misko TP, Schilling RJ, Salvemini D, Moore WM, Currie MG. A fluorimetric assay for the measurement of nitrite in biological samples. Anal Biochem. 1993;214:11-6.

25. Moroney MA, Alcaraz MJ, Forder RA, Carey F, Hoult JRS. Selectivity of neutrophil 5-lipoxygenase and cyclo-oxygenase inhibitor by an anti-inflammatory flavonoid glycoside and releated aglycone flavonoids. J Pharm. Pharmacol. 1988;40:787-92. 
26. Choi CY, Kim JY, Kim YS, Chung YC, Hahm KS, Jeong HG. Aqueous extract isolated from Platycodon grandiflorum elicits the release of nitric oxide and tumor necrosis factor-alpha from murine macrophages. Int Immunopharmacol. 2001;1:114151.

27. Giacometti J. Determination of aliphatic alcohols, squalene, alpha-tocopherol and sterols in olive oils: direct method involving gas chromatography of the unsaponifiable fraction following silylation. Analyst. 2001;126:472-5.

28. Castaño G; Fernández L, Mas R, Illnait J, Gámez R, Mendoza S, Mesa M, Fernández J. Effects of addition of policosanol to omega-3 fatty acid therapy on the lipid profile of patients with type II hypercholesterolaemia; Drugs. 2005;6:207-19.

29. Dulin MF, Hatcher LF, Sasser HC, Barringer TA. Policosanol is ineffective in the treatment of hypercholesterolemia: a randomized controlled trial. Am J Clin Nutr. 2006;84:1543-8.

30. Ross R. Atherosclerosis: an inflammatory disease. N Engl J Med. 1999;340:11526.

31. van Oostrom AJ, van Wijk J; Cabezas MC. Lipaemia, inflammation and atherosclerosis: novel opportunities in the understanding and treatment of atherosclerosis. Drugs. 2004;64:19-41.

32. Libby P. Inflammation in atherosclerosis. Nature. 2002);420:868-74.

33. Shinbori C, Saito M, Kinoshita Y, Satoh I, Kono T, Hanada T, Nanba E, Adachi K, Suzuki H, Yamada M, Satoh K. Cyclohexenonic long-chain fatty alcohol has therapeutic effects on diabetes-induced angiopathy in the rat aorta. Eur J Pharmacol. 2007;567:139-44.

34. Chen JC, Huang KC, Lin WW. HMG-CoA reductase inhibitors upregulate heme oxygenase-1 expression in murine RAW264.7 macrophages via ERK, p38 MAPK and protein kinase G pathways. Cell Signal. 2006;18:32-9.

35. McCarty MF. Down-regulation of microglial activation may represent a practical strategy for combating neurodegenerative disorders. Med Hypotheses. 2006;67:25169.

36. Huang KC, Chen CW, Chen JC, Lin WW. HMG-CoA reductase inhibitors inhibit inducible nitric oxide synthase gene expression in macrophages. J Biomed Sci. 2003;10:396-405.

37. Saito M, Kinoshita Y, Satoh I, Shinbori C, Kono T, Hanada T, Uemasu J, Suzuki H, Yamada M, Satoh K. N-hexacosanol ameliorates streptozotocin-induced diabetic rat nephropathy. Eur J Pharmacol. 2006 21;544:132-7. 
38. Muller T, Grandbarbe L, Morga E, Heuschling P, Luu B. Tocopherol long chain fatty alcohols decrease the production of TNF-alpha and NO radicals by activated microglial cells. Bioorg Med Chem Lett. 2004;14:6023-6.

39. D'Acquisto F, luvone T, Rombola L, Sautebin L, Di Rosa M, Carnuccio R. Involvement of NF-kappaB in the regulation of cyclooxygenase-2 protein expression in LPS-stimulated J774 macrophages. FEBS Lett. 1997;418:175-8.

40. Dogne JM, de Leval X, Hanson J, Frederich M, Lambermont B, Ghuysen A, Casini

A, Masereel B, Ruan KH, Pirotte B, Kolh P. New developments on thromboxane and prostacyclin modulators part I: thromboxane modulators. Curr Med Chem. 2004;11:1223-41.

41. Arruzazabala ML, Molina V, Mas R, Fernandez L; Carbajal D, Valdes S, Castaño G. Antiplatelet effects of policosanol (20 and $40 \mathrm{mg} /$ day) in healthy volunteers and dyslipidaemic patients. Clin Exp Pharmacol. Physiol. 2002;29:891-7.

42. Cabello-Moruno R, Perona JS, Osada J, Garcia M, Ruiz-Gutierrez V. Modifications in postprandial triglyceride-rich lipoprotein composition and size after the intake of pomace olive oil. J Am Coll Nutr. 2007;26:24-31. 


\section{FIGURE LEGENDS}

Figure 1. Gas chromatogram of the LCFA fraction from pomace olive oil (POO). Retention times and carbon numbers are shown on the peaks. $\mathrm{C} 21 \mathrm{OH}$ : monocosanol; $\mathrm{C} 22 \mathrm{OH}$ : docosanol; $\mathrm{C} 23 \mathrm{OH}$ : tricosanol; $\mathrm{C} 24 \mathrm{OH}$ : tetracosanol; $\mathrm{C} 25 \mathrm{OH}$ : pentacosanol; $\mathrm{C} 26 \mathrm{OH}$ : hexacosanol; $\mathrm{C} 27 \mathrm{OH}$ : heptacosanol; $\mathrm{C} 28 \mathrm{OH}$ : monocosanol; $\mathrm{C} 29 \mathrm{OH}$ : nonacosanol; $\mathrm{C} 30 \mathrm{OH}$ : triacontanol.

Figure 2. Effect of LCFA on human recombinat synovial phospholipase $A_{2}$ activity. Results show means \pm SEM from 3 different experiments $\left({ }^{*} p<0.05{ }^{* *} p<0.01\right.$ versus control). Control: total PLA $\mathrm{P}_{2}$ enzyme activity. The LCFA fraction was extracted from $\mathrm{POO}$ as described in the Methods and Materials section.

Figure 3. Effect of LCFA on the production of nitrite (A), PGE $2(B)$ and TNF- $\alpha(C)$ by LPS-stimulated RAW-264.7 murine macrophages. Cells $\left(1 \times 10^{6}\right.$ cells $\left./ \mathrm{ml}\right)$ were incubated with LPS $(10 \mu \mathrm{g} / \mathrm{ml})$ in the presence of different LCFA concentrations. Each value represents the mean \pm S.E.M. for more than two triplicate experiments. ${ }^{* *}: p<0.01$; ${ }^{* * *}: p<0.001$ versus LPS control group. The LCFA fraction was extracted from POO as described in the Methods and Materials section.

Figure 4. Effect of LCFA on iNOS expression by RAW 264.7 cells. The figure is representative of three similar experiments. B:unstimulated cells; LPS: LPS-stimulated cells; Dex: LPS stimulated cells treated with dexamethasone at $10 \mu \mathrm{M}$; LCFA: LPS stimulated cells treated with LCFA at $100 \mu \mathrm{g} / \mathrm{ml}$. Calculation of iNOS expression after LCFA or dexamethasone treatments relative to LPS-stimulated cells was carried out by means of densitometric analysis (O.D.). The LCFA fraction was extracted from POO as described in the Methods and Materials section.

Figure 5. Effect of LCFA on $\mathrm{TXB}_{2}$ production by peritoneal rat neuthrophils $\left(2.5 \times 10^{6}\right.$ cell/ml) stimulated with the calcium ionophore A23187. Each value represents the mean \pm S.E.M. for three triplicate experiments. ${ }^{*}: p<0.05 ;{ }^{* * *}: p<0.001$ versus calcium ionophore A23187 control group. The LCFA fraction was extracted from POO as described in the Methods and Materials section. 
Table 1. Composition of the LCFA fraction from pomace olive oil (POO) analyzed by gas-chromatography.

\begin{tabular}{lll}
\hline & Composition (\%) & NAME \\
$\mathrm{C}_{20} \mathrm{H}_{40} \mathrm{O}$ & 1.9 & phytol \\
$\mathrm{C}_{20} \mathrm{H}_{34} \mathrm{O}$ & 2.0 & geranylgeraniol \\
$\mathrm{C}_{22} \mathrm{OH}$ & 7.5 & docosanol \\
$\mathrm{C}_{23} \mathrm{OH}$ & 0.8 & tricosanol \\
$\mathrm{C}_{24} \mathrm{OH}$ & 30.3 & tetracosanol \\
$\mathrm{C}_{25} \mathrm{OH}$ & 1.9 & pentacontanol \\
$\mathrm{C}_{26} \mathrm{OH}$ & 37.3 & hexacosanol \\
$\mathrm{C}_{27} \mathrm{OH}$ & 1.5 & heptacontanol \\
$\mathrm{C}_{28} \mathrm{OH}$ & 15.3 & octacosanol \\
$\mathrm{C}_{29} \mathrm{OH}$ & 0.3 & nonacosanol \\
$\mathrm{C}_{30} \mathrm{OH}$ & 1.1 & triacontanol \\
\hline
\end{tabular}




\section{Figure(s)}

Click here to download high resolution image

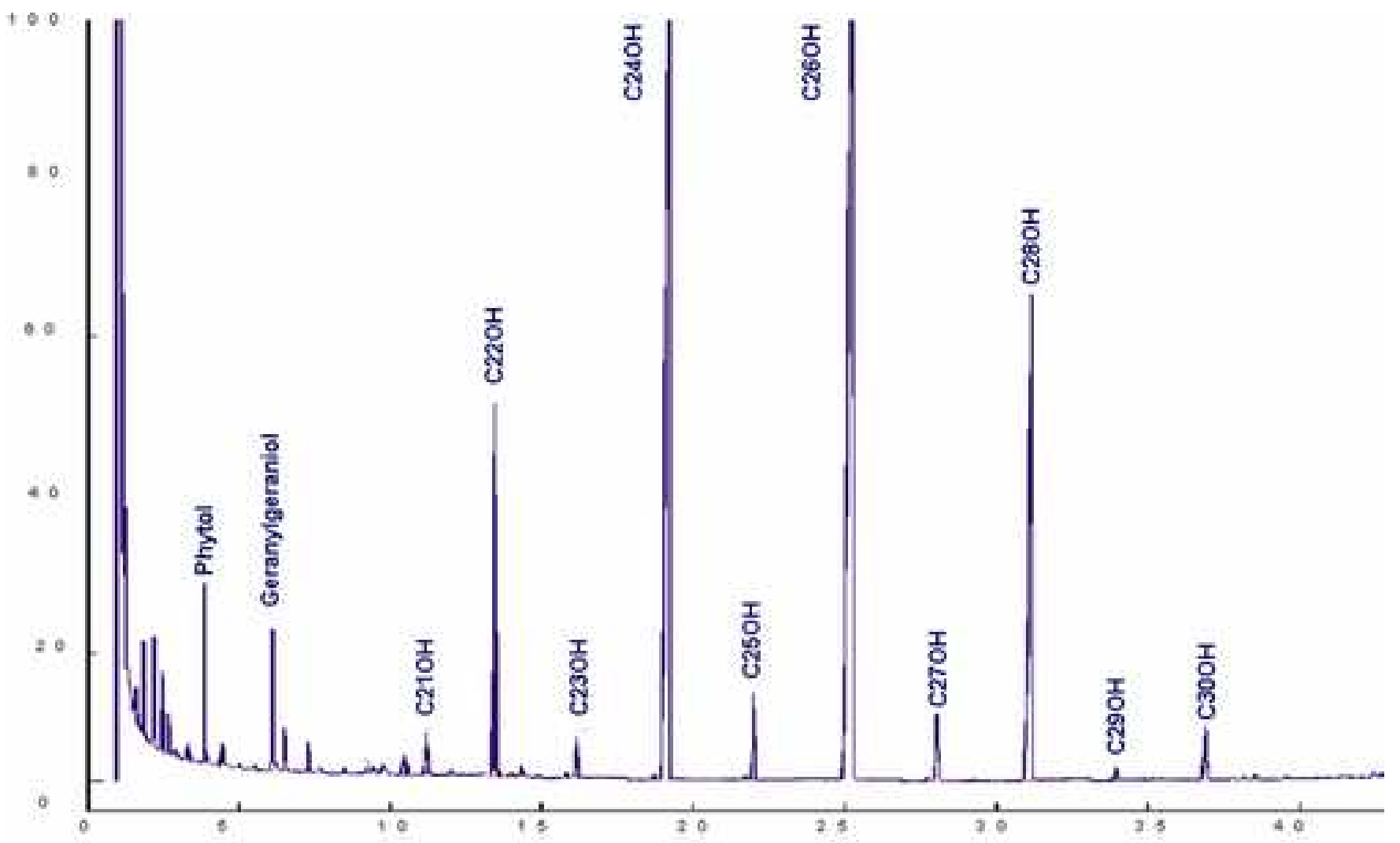


Figure(s)
Click here to download high resolution image

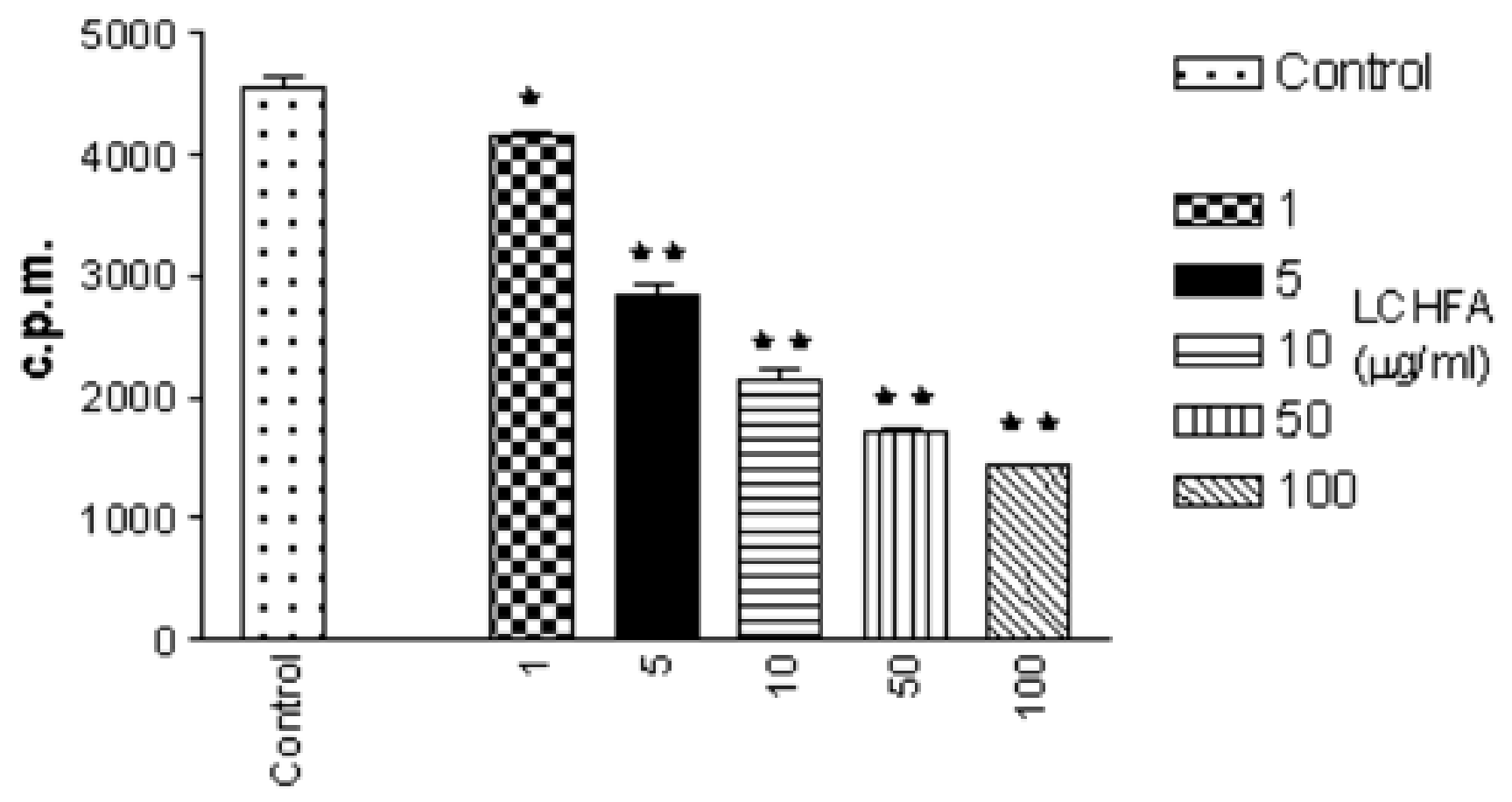


Figure(s)
Click here to download high resolution image

A)

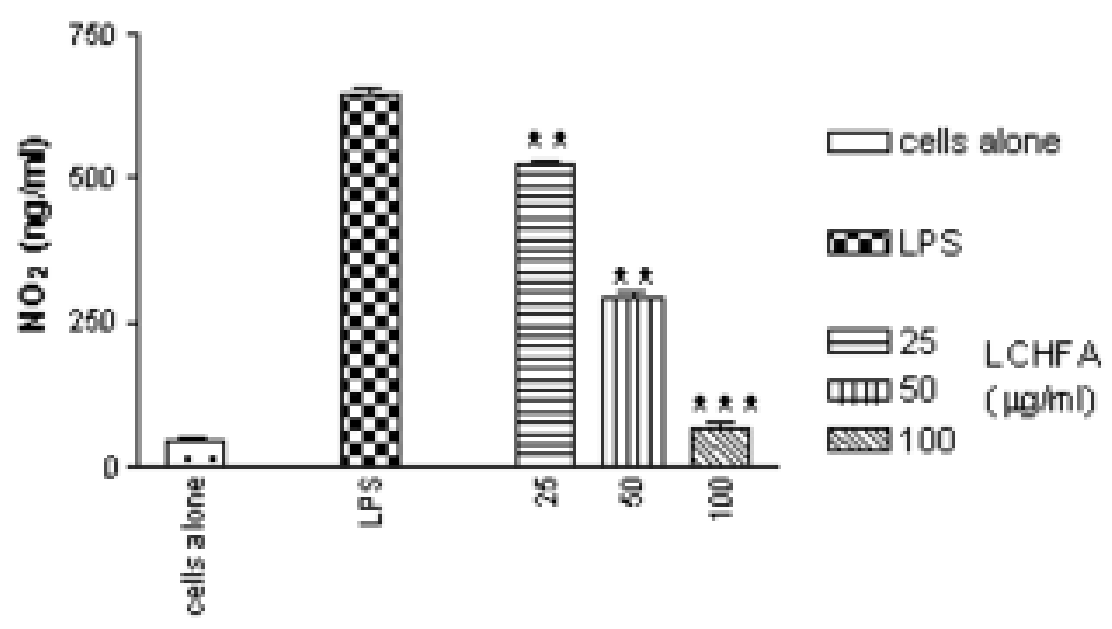

B)

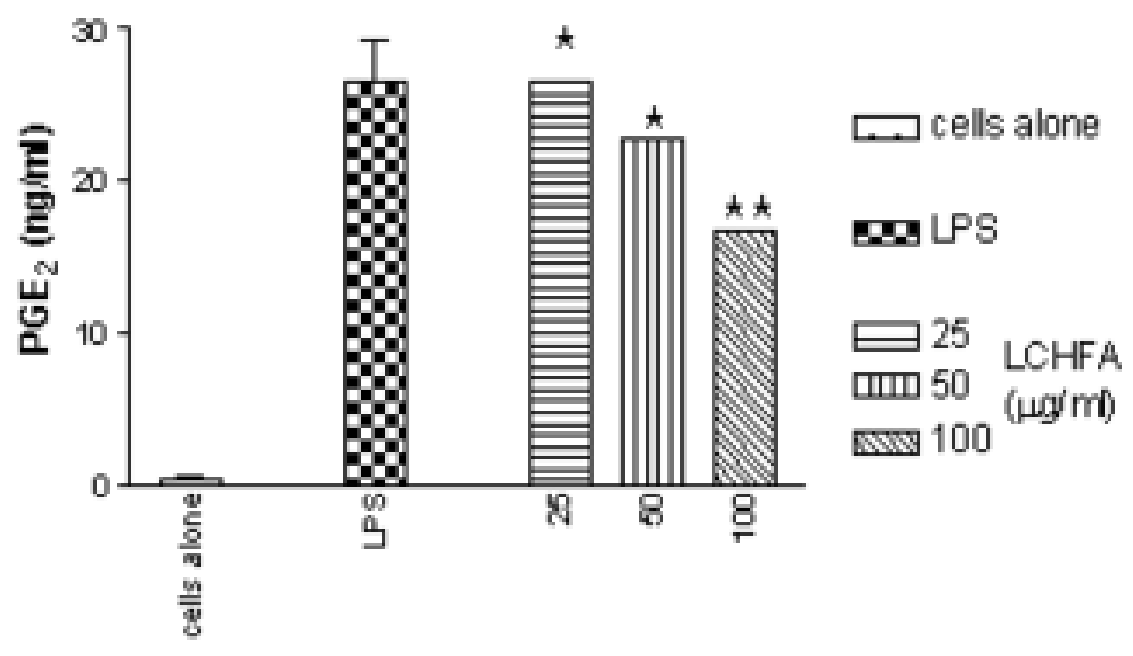

C)

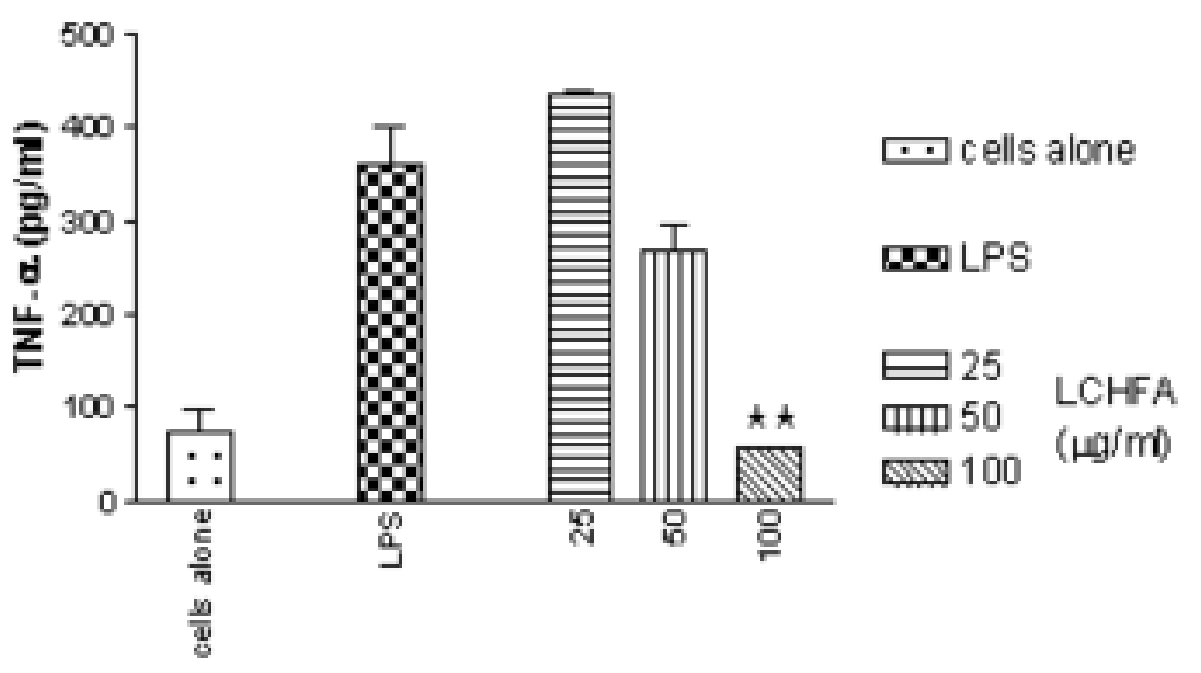


Click here to download high resolution image

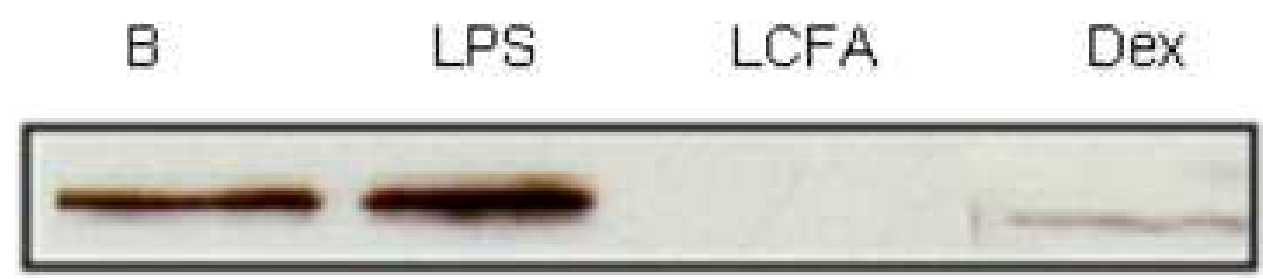

$\begin{array}{lllll}\% & 0 D & 40 & 100 & 0\end{array}$

4


Figure(s)
Click here to download high resolution image

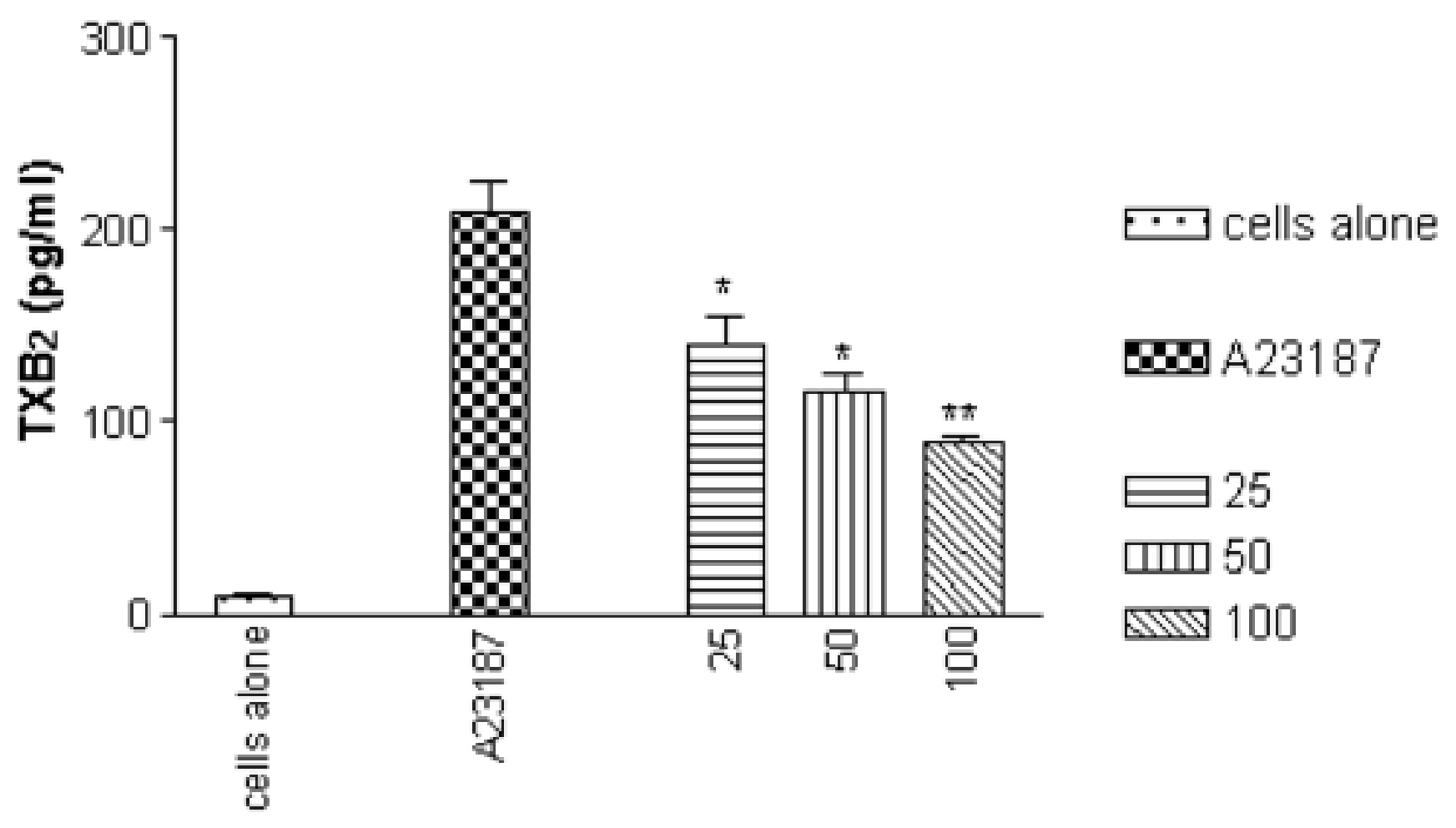

